\title{
KEMANDIRIAN BELAJAR SISWA MEMPELAJARI POKOK BAHASAN PENCEMARAN LINGKUNGAN MENGGUNAKAN MODUL PRAKTIKUM IPA BEBASIS INKUIRI
}

\author{
Ira Nofita Sari' ${ }^{1}$, Erna Octavia ${ }^{2}$ \\ ${ }^{\text {I} P r o g r a m ~ S t u d i ~ P e n d i d i k a n ~ F i s i k a, ~ F a k u l t a s ~ P e n d i d i k a n ~ M I P A ~ d a n ~ T e k n o l o g i, ~ I K I P ~ P G R I ~ P o n t i a n a k ~}$ \\ ${ }^{2}$ Program Studi Pendidikan Pancasila dan Kewarganegaraan, Fakultas Pendidikan IPS, IKIP PGRI Pontianak \\ Email: iranofitasari87@gmail.com ${ }^{1}$,erna8649@yahoo.com ${ }^{2}$
}

INFO ARTIKEL
Riwayat Artikel:
$\begin{array}{ll}\text { Menerima } & : 24 \text { Agustus } 2020 \\ \text { Revisi } & : 20 \text { Oktober } 2020 \\ \text { Diterima } & : 20 \text { Nopember } 2020\end{array}$

\section{Kata Kunci:}

Kemandirian Belajar, Modul, Praktikum, IPA, Inkuiri

\begin{abstract}
ABSTRAK
Kemandirian merupakan hal yang diperhitungkan dalam melaksanakan pembelajaran guna mengembangkan potensi siswa secara maksimal. Tujuan penelitian ini adalah untuk mengetahui kemandirian belajar siswa memepelajari materi pencemaran lingkungan menggunakan modul praktikum IPA berbasis inkuiri. Metode yang digunakan dalam penelitian ini adalah metode eksperimen dalam bentuk pre experimental design.Populasi penelitain ini adalah SMP Swasta Advent Singkawang Kalimantan Barat Melalui teknik sampling jenuh, diketahui bahwa kelas VII A merupakan kelas yang digunakan sebagai kelas eksperimen. Untuk mengetahui kemandirian belajar siswa, digunakan angket kemandirian belajar. Berdasarkan hasil analisis data diketahui bahwa rata-rata kemandirian belajar siswa tergolong sangat baik.
\end{abstract}

\section{ABSTRACT}

Independence is a thing that is taken into account in carrying out learning in order to develop the maximum potential of students. The purpose of this study was to determine the independent learning of students studying environmental pollution material using inquiry-based science practicum modules. The method used in this research is the experimental method. The population of this research is SMP Private Advent Singkawang, West Kalimantan. Through saturated sampling technique, it is known that class VII A is the class used as the experimental class. To find out students' learning independence, a learning independence questionnaire was used. Based on the results of data analysis, it is known that the average student learning independence is very good.

(C)2020 LPPM STKIP Persada Khatulistiwa Sintang

\section{PENDAHULUAN}

Tujuan pendidikan nasional yaitu untuk berkembangnya potensi peserta didik agar menjadi manusia yang beriman, berakhlak mulia, sehat, berilmu, cakap, kreatif, mandiri, dan menjadi warga negara yang demokratis serta bertanggung jawab (Lutfi, dkk., 2012). Tujuan pendidikan tersebut harus tetap tercapai melalui pembelajaran dengan kondisi apapun. Sama halnya seperti saat ini, di tengah pandemi Covid-19 kegiatan pembelajaran harus berlangsung dengan tetap memperhatikan amanah tujuan pendidikan dan amanah pemerintah dengan physical distancing yang mengaharuskan siswa untuk study from home (belajar dari rumah).

Adanya kebijakan ini mengharuskan para akademisi, termasuk di dalamnya guru untuk memikirkan cara yang efektif untuk 
melakukan pembelajaran dari rumah. Salah satu cara yang ditempuh yaitu dengan menggunakan modul.

Penggunaan modul merupakan salah satu cara yang tepat dalam menerapkan pembelajaran secara mandiri yang dilakukan oleh setiap siswa dari rumah masing-masing. Menurut Muhafid, dkk. (2013) modul adalah bahan belajar yang dirancang secara sistematis berdasarkan kurikulum tertentu dan dikemas dalam bentuk satuan pembelajaran terkecil dan memungkinkan dipelajari secara mandiri dalam suatu waktu tertentu. Modul yang diterapkan dalam pembelajaran kali ini merupakan modul praktikum IPA berbasis inkuiri untuk mempelajari materi IPA. Modul ini dikemas dalam bentuk mobile learning.

Mobile Learning adalah pembelajaran secara elektronik yang dapat diakses dengan smartphone atau gawai (Pradana, dkk., 2020).

Modul praktikum IPA ini merupakan modul yang telah diintegrasikan menggunakan model inkuri. Menurut Welch (Suparno, 2007) secara umum, inkuiri adalah proses dimana manusia mencari informasi atau pengertian dari a way of thought. Pembelajaran inkuiri merupakan cara yang tepat dilakukan untuk melaksanakan pembelajaran melaui proses mencari informasi. Modul praktikum IPA berbasis inkuiri merupakan bahan belajar yang dirancang secara sistematis berdasarkan kurikulum 2013 yang dapat digunakan siswa untuk meningkatkan kompetensi dan memenuhi kebutuhan dalam berbagai situasi. Modul penuntun praktikum berbasis inkuiri merupakan petunjuk praktikum yang dapat menuntun siswa untuk melakukan penyelidikan dan penemuan terhadap konsepkonsep dan langkah-langkah; orientasi, perumusan masalah, perumusan hipotesis, mengumpulkan data, menguji hipotesis, dan merumuskan kesimpulan (Sanjaya, 2008).

Peraturan Presiden Republik Indonesia No. 87 Tahun 2017 tentang penguatan pendidikan karakter yang menyatakan bahwa dalam rangka mewujudkan bangsa yang berbudaya melalui penguatan nilai-nilai religius, jujur, toleran, disiplin, bekerja keras, kreatif, mandiri, demokratis, rasa ingin tahu, semangat kebangsaan, cinta tanah air, menghargai prestasi, komunikatif, cinta damai, gemar membaca, peduli longkungan, peduli sosial, dan bertanggung jawab perlu penguatan pendidikan karakter.

Bertolak dari amanah Pepres tersebut maka penting untuk memerlukan aspek-aspek pendidikan karakter, salah satunya adalah kemandirian. Kemandirian dalam belajar adalah aktivitas belajar yang berlangsungnya dengan dorongan kemauan sendiri, pilihan sendiri dan tanggung jawab sendiri oleh siswa (Anzora, 2017). Melalui modul praktikum IPA berbasis inkuiri, siswa diberikan kesempatan untuk belajar mandiri dalam menemukan konsep IPA. Berdasarkan paparan di atas maka melalui implementasi modul prakrikum IPA berbasis inkuiri diharapkan dapat kemandirian belajar siswa sesuai harapan tujuan pendidikan nasional.

\section{METODE PENELITIAN}

Penelitian ini dilaksanakan di SMP Swasta Advent Singkawang Kalimantan Barat. Penelitian dilaksanakan pada semester genap 
Tahun Akademik 2019/2020. Metode yang digunakan dalam penelitian ini adalah metode eksperimen dalam bentuk pre experimental design.

Populasi dalam penelitian ini adalah seluruh siswa SMP Swasta Advent yang terdiri dari satu kelas VII. Dengan teknik sampling jenuh diperoleh sampel penelitian yaitu seluruh siswa kelas VII A SMP Swasta Advent yang berjumlah 16 orang.

Teknik pengumpulan data yang akan digunakan dalam penelitian ini adalah teknik pengukuran. Alat pengumpul data yang digunakan adalah angket respon kemandirian belajar siswa yang disebar menggunakan google form. Angket kemandirian belajar meliputi aspek percaya diri, disiplin, inisiatif, tanggung jawab dan motivasi dengan pernyataan sebanyak 36 item. Angket kemandirian belajar diberikan setelah siswa melakukan pembelajaran menggunakan modul praktikum IPA berbasis inkuri.

Data yang diperoleh dari angket siswa, selanjutnya diolah dan dianalisis sesuai dengan masalah dan tujuan yang telah dirumuskan. Untuk mengetahui kemandirian belajar siswa dalam mempelajari pokok bahasan pencemaran menggunakan modul praktikum IPA berbasis inkuiri dilakukan dengan cara mendeskripsikan bagaimana hasil penerapan modul praktikum IPA berbasis inkuri terhadap kemandirian belajar siswa.

Data respon siswa yang berupa data kuantitatif dianalisis secara deskriptif untuk mencari kemandirian belajar setiap siswa. Data yang diperoleh selanjutnya dianalisis menggunakan perhitungan skor ideal untuk mengidentifikasi distribusi frekuaensi \% skor ideal. Kriteria ideal diperoleh dengan mencari skor maksimal ideal, mencari skor minimal ideal, menghitung mean ideal dan standar deviasi ideal. Setelah diketahui kriteria ideal, selanjutnya dikategorikan menggunakan Tabel 1 yang kemudian dipersentasikan menggunakan Tabel 2 (Arikunto, 2006).

Tabel 1. Interpretasi Angket Kemandirian Belajar

\begin{tabular}{ll}
\hline $\begin{array}{r}\text { Kategori } \\
\text { Penilaian }\end{array}$ & \multicolumn{2}{c}{ Interpretasi Angket } \\
\hline Sangat Baik & $\begin{array}{l}\text { Siswa selalu melakukan hal } \\
\text { yang berhubungan dengan } \\
\text { percaya diri, disiplin, inisiatif, } \\
\text { tanggung jawab dan motivasi. }\end{array}$ \\
\hline Baik & $\begin{array}{l}\text { Siswa sering melakukan hal } \\
\text { yang berhubungan dengan } \\
\text { percaya diri, disiplin, inisiatif, } \\
\\
\text { tanggung jawab dan motivasi. }\end{array}$ \\
\hline Cukup Baik & $\begin{array}{l}\text { Siswa jarang melakukan hal } \\
\text { yang berhubungan dengan } \\
\text { percaya diri, disiplin, inisiatif, } \\
\text { tanggung jawab dan motivasi. }\end{array}$ \\
\hline Kurang Baik & $\begin{array}{l}\text { Siswa tidak pernah } \\
\text { melakukan hal yang } \\
\end{array}$ \\
& $\begin{array}{l}\text { berhubungan dengan percaya } \\
\text { diri, disiplin, inisiatif, } \\
\text { tanggung jawab dan motivasi. }\end{array}$ \\
\hline
\end{tabular}

Tabel 2. Kategori Kemandirian Belajar Siswa

\begin{tabular}{cc}
\hline Persentase $(\%)$ & Kategori \\
\hline $90-100$ & Sangat Mandiri \\
$70-89$ & Mandiri \\
$60-69$ & Cukup Mandiri \\
$50-59$ & Kurang Mandiri \\
$0-49$ & Sangat Kurang Mandiri \\
\hline
\end{tabular}

\section{HASIL DAN PEMBAHASAN}

Salah satu cara yang ditempuh untuk melakukan pembelajaran IPA secara daring yang diterapkan pada masa pandemi Covid-19 ini menggunakan modul praktikum IPA berbasis inkuri dikemas dalam bentuk mobile learning. Pada awal pembelajaran siswa SMP 
Swasta Advent kelas VII A dibentuk grup belajar yang tergabung dalam whatsapp group. Grup ini dibuat untuk memudahkan guru dalam melakukan pembelajaran IPA termasuklah di dalamnya memberikan materi pelajaran, memberikan latihan soal, maupun tes.

Modul praktikum IPA berbasis inkuri yang dikemas dalam bentuk mobile learning merupakan salah satu cara yang dapat memudahkan guru dan siswa untuk tetap melaksanakan pembelajaran melalui konsep study from home dan physical distancing. Pertama, Modul praktikum IPA berbasis inkuri di-share kemudian diinstal ke smartphone setiap siswa melalui whatsapp group. Kedua, guru memilah tema yang akan dipelajari oleh siswa dan memberikan penjelasan singkat terkait penggunaan modul praktikum IPA berbasis inkuri melalui aplikasi zoom. Adapun tema yang dipelajari adalah pemcemaran lingkungan. Tahapan inkuri pada modul meliputi orientasi, merumuskan masalah, meyampaikan hipotesis, mengumpulkan data, menguji hipotesis, dan membuat kesimpulan. Melalui modul ini siswa akan belajar secara mandiri untuk menemukan konsepnya sendiri atau dengan kata lain dengan ber-inkuiri. Ketiga, siswa belajar secara mandiri di rumah, hasil pengerjaan modul yang terdiri dari jawaban pertanyaan dan pelaksanaan eksperimen sederhana di dokumentasikan kemudian dilaporkan ke guru dalam bentuk foto. Keempat guru memberikan umpan balik terhadap konsep yang telah diperoleh siswa. Pada tahap ini siswa diminta untuk menyajikan konsep yang telah diperolehnya melalui modul praktikum IPA berbasis inkuiri. Kelima guru memberikan penguatan terhadap konsep yang telah diperoleh siswa. Tahap keempat dan kelima ini juga dilakukan secara online menggunakan aplikasi zoom. Keenam guru memberikan angket kemandirian belajar siswa setelah menggunakan modul praktikum IPA berbasis inkuiri menggunakan google form. Pernyataan yang digunakan untuk megidentifikasi kemandirian belajar siswa berjumlah 36 item pernyataan yang terdiri dari indikator yang menggambarkan kemandirian belajar yaitu percaya diri, disiplin, inisiatif, tanggung jawab dan motivasi. Secara singkat tahapan pembelajaran menggunakan modul praktikum IPA berbasis inkuri pada materi pencemaran untuk melihat kemandirian belajar siswa SMP pada masa pandemi Covid-19 disajikan pada Gambar 1.

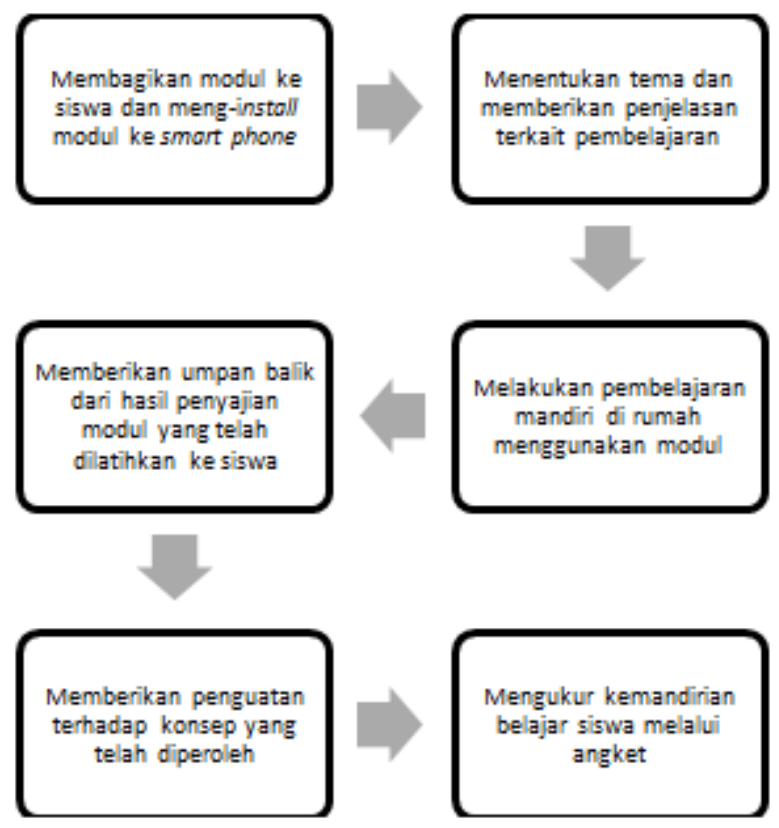

Gambar 1. Tahapan Pembelajaran Menggunakan Modul Praktikum IPA Berbasis Inkuri pada Materi Pencemaran 
Setelah diperoleh data kemandirian belajar siswa dari angket kemandirian belajar siswa, selanjutnya data tersebut diolah secara dekriptif melalui Tabel 2 dan diperoleh hasil yang dapat dilihat Tabel 3.

Tabel 3. Kemandirian Belajar Siswa

Mempelajari Pokok Bahasan Pencemaran Lingkungan Menggunakan Modul Praktikum Berbasis Inkuiri

\begin{tabular}{ccl}
\hline $\begin{array}{c}\text { Aspek } \\
\text { Kemandirian }\end{array}$ & $(\%)$ & Kategori \\
\hline Percaya diri & 81,60 & Mandiri \\
\hline Disiplin & 74,22 & Mandiri \\
\hline Inisiatif & 78,82 & Mandiri \\
\hline Tanggung jawab & 76,30 & Mandiri \\
\hline Motivasi & 80,73 & Mandiri \\
\hline
\end{tabular}

Berdasarkan Tabel 3 diketahui bahwa secara umum kemandirian belajar siswa temasuk dalam kategori sangat baik yang artinya siswa mandiri. Hal ini sejalan dengan Uswatun (2012) bahwa pembelajaran menggunakan modul adalah pendekatan belajar mandiri.

Penilaian kemandirian belajar siswa juga dilihat untuk setiap aspeknya. Berdasarkan analisis data diketahui bahwa penilaian kemandirian belajar pada aspek percaya diri dapat dilihat pada Tabel 4.

Tabel 4. Kemandirian Belajar Siswa Mempelajari Pokok Bahasan Pencemaran Lingkungan Menggunakan Modul Praktikum Berbasis Inkuiri pada Aspek Percaya Diri

\begin{tabular}{cccl}
\hline $\begin{array}{c}\text { Kelas } \\
\text { Interval }\end{array}$ & $\begin{array}{c}\text { Frekuensi } \\
(\mathrm{f})\end{array}$ & $\begin{array}{c}\text { Frekuensi } \\
(\%)\end{array}$ & Kategori \\
\hline $\mathrm{X}>30$ & 10 & 62,50 & $\begin{array}{l}\text { Sangat } \\
\text { Baik }\end{array}$ \\
\hline $22,5<\mathrm{X} \leq 30$ & 4 & 25,00 & Baik \\
\hline $15<\mathrm{X} \leq 22,5$ & 2 & 12,50 & $\begin{array}{l}\text { Cukup } \\
\text { Baik }\end{array}$ \\
\hline $\mathrm{X} \leq 15$ & 0 & 0,00 & $\begin{array}{l}\text { Kurang } \\
\text { Baik }\end{array}$ \\
\hline
\end{tabular}

Berdasarkan Tabel 4 terlihat bahwa sebanyak $62,50 \%$ siswa memiliki kemandirian belajar pada aspek percaya diri sangat baik. Siswa selalu melakukan hal yang berhubungan dengan percaya diri. Dalam hal ini siswa dapat menyampaikan hasil/temuannya di forum. Siswa mempresentasikan jawaban pertanyaan terhadap konsep yang ditemukannya melalui proses belajar menggunakan modul praktikum IPA berbasis inkuiri pada materi pencemaran. Siswa menyampaikan hasil temuannya secara invidu kepada teman-temannya dengan percaya diri melalui aplikasi zoom. Siswa yang lain juga menanggapi temannya yang menyajikan presentasi pada saat tanya jawab. Seluruh siswa terlibat dalam forum diskusi ini. Sejalan dengan Suryani (2018) bahwa kemampuan siswa dalam berkomunikasi merupakan salah satu indikator kepercayaan diri pada siswa. Siswa yang takut menerima tanggapan atau penilaian negatif dari komunikan dan sulit berkonsentrasi merupakan penyebab ketidakpercayaan diri.

Tabel 5. Kemandirian Belajar Siswa Mempelajari Pokok Bahasan Pencemaran Lingkungan Menggunakan Modul Praktikum Berbasis Inkuiri pada Aspek Disiplin

\begin{tabular}{cccl}
\hline $\begin{array}{c}\text { Kelas } \\
\text { Interval }\end{array}$ & $\begin{array}{c}\text { Frekuensi } \\
\text { (f) }\end{array}$ & $\begin{array}{c}\text { Frekuensi } \\
(\%)\end{array}$ & Kategori \\
\hline $\mathrm{X}>19,5$ & 3 & 18,75 & $\begin{array}{l}\text { Sangat } \\
\text { Baik }\end{array}$ \\
\hline $15<\mathrm{X} \leq 19,5$ & 11 & 68,75 & Baik \\
\hline $10,5<\mathrm{X} \leq 15$ & 2 & 12,50 & $\begin{array}{l}\text { Cukup } \\
\text { Baik }\end{array}$ \\
\hline $\mathrm{X} \leq 10,5$ & 0 & 0,00 & $\begin{array}{l}\text { Kurang } \\
\text { Baik }\end{array}$ \\
\hline
\end{tabular}

Berdasarkan Tabel 5 terlihat bahwa sebanyak $68,75 \%$ siswa memiliki kemandirian belajar pada aspek disiplin dengan kategori baik. Siswa sering melakukan hal yang berhubungan dengan disiplin. Siswa menerapkan sikap 
disiplin dalam melakukan pembelajaran.

Terlihat dari hasil pekerjaan siswa dikumpulkan secara berurutan sesuai arahan, peraturan dan waktu yang ditentukan dalam penggunaan modul IPA berbasis inkuiri pada materi pencemaran. Disiplin yang ditunjukkan oleh siswa melalui hasil angket ini sejalan dengan pengertian disiplin yang disampaikan oleh Santoso, dkk. (2018) yang diartikan sebagai perilaku dan tata tertib yang sesuai dengan peraturan dan ketetapan, atau perilaku yang diperoleh dari pelatihan.

Tabel 6. Kemandirian Belajar Siswa Mempelajari Pokok Bahasan Pencemaran Lingkungan Menggunakan Modul Praktikum Berbasis Inkuiri pada Aspek Inisiatif

\begin{tabular}{cccl}
\hline $\begin{array}{c}\text { Kelas } \\
\text { Interval }\end{array}$ & $\begin{array}{c}\text { Frekuensi } \\
(\mathrm{f})\end{array}$ & $\begin{array}{c}\text { Frekuensi } \\
(\%)\end{array}$ & Kategori \\
\hline $\mathrm{X}>30$ & 7 & 43,75 & $\begin{array}{l}\text { Sangat } \\
\text { Baik }\end{array}$ \\
\hline $22,5<\mathrm{X} \leq 30$ & 6 & 37,50 & Baik \\
\hline $7<\mathrm{X} \leq 22,5$ & 3 & 18,75 & $\begin{array}{l}\text { Cukup } \\
\text { Baik }\end{array}$ \\
\hline $\mathrm{X} \leq 15$ & 0 & 0,00 & $\begin{array}{l}\text { Kurang } \\
\text { Baik }\end{array}$ \\
\hline
\end{tabular}

Berdasarkan Tabel 6 terlihat bahwa sebanyak $43,75 \%$ siswa memiliki kemandirian belajar pada aspek inisiatif dengan kategori sangat baik. Siswa selalu melakukan hal yang berhubungan dengan inisiatif. Hal ini terlihat dari keingintahuan siswa yang besar terhadap pengalaman baru dan keinginan untuk meneliti. Model inkuri yang mengarahkan siswa untuk melakukan penemuan melalui eksperimen yang disajikan dalam bentuk modul praktikum IPA ini membuat siswa tertantang untuk menemukan konsepnya secara mandiri. Siswa menemukan hal yang baru dengan belajar sendiri dan mealakukan penyelidikan.

Berdasarkan Tabel 7 terlihat bahwa sebanyak $43,75 \%$ siswa memiliki kemandirian belajar pada aspek tanggung jawab dengan kategori baik.

Tabel 7. Kemandirian Belajar Siswa Mempelajari Pokok Bahasan Pencemaran Lingkungan Menggunakan Modul Praktikum Berbasis Inkuiri pada Aspek Tanggung Jawab

\begin{tabular}{cccl}
\hline $\begin{array}{c}\text { Kelas } \\
\text { Interval }\end{array}$ & $\begin{array}{c}\text { Frekuensi } \\
(\mathrm{f})\end{array}$ & $\begin{array}{c}\text { Frekuensi } \\
(\%)\end{array}$ & Kategori \\
\hline $\mathrm{X}>19,5$ & 6 & 37,50 & $\begin{array}{l}\text { Sangat } \\
\text { Baik }\end{array}$ \\
\hline $15<\mathrm{X} \leq 19,5$ & 7 & 43,75 & Baik \\
\hline $10,5<\mathrm{X} \leq 15$ & 3 & 18,75 & $\begin{array}{l}\text { Cukup } \\
\text { Baik }\end{array}$ \\
\hline $\mathrm{X} \leq 10,5$ & 0 & 0,00 & $\begin{array}{l}\text { Kurang } \\
\text { Baik }\end{array}$ \\
\hline
\end{tabular}

Siswa sering melakukan hal yang berhubungan dengan tanggung jawab.

Hal ini terbukti dari komitmen siswa terhadap tugas yang diberikan. Siswa menyelesaikan tugas yang diberikan dengan penuh tanggung jawab. Terlihat dari saat melakukan praktikum, siswa melakukanya dengan sungguh-sungguh dengan mengirimkan bukti video eksperimen yang dilakukannya.

Tabel 8. Kemandirian Belajar Siswa Mempelajari Pokok Bahasan Pencemaran Lingkungan Menggunakan Modul Praktikum

Berbasis Inkuiri pada Aspek Motivasi

\begin{tabular}{cccl}
\hline $\begin{array}{c}\text { Kelas } \\
\text { Interval }\end{array}$ & $\begin{array}{c}\text { Frekuensi } \\
(\mathrm{f})\end{array}$ & $\begin{array}{c}\text { Frekuensi } \\
(\%)\end{array}$ & Kategori \\
\hline $\mathrm{X}>19,5$ & 8 & 50,00 & $\begin{array}{l}\text { Sangat } \\
\text { Baik }\end{array}$ \\
\hline $15<\mathrm{X} \leq 19,5$ & 7 & 43,75 & Baik \\
\hline $10,5<\mathrm{X} \leq 15$ & 1 & 6,25 & $\begin{array}{l}\text { Cukup } \\
\text { Baik }\end{array}$ \\
\hline $\mathrm{X} \leq 10,5$ & 0 & 0,00 & $\begin{array}{l}\text { Kurang } \\
\text { Baik }\end{array}$ \\
\hline
\end{tabular}

Berdasarkan Tabel 8 terlihat bahwa sebanyak 50,00\% siswa memiliki kemandirian belajar pada aspek motivasi dengan kategori 
sangat baik. Siswa selalu melakukan hal yang berhubungan dengan motivasi. Siswa berusaha untuk mencapai hasil yang maksimal dalam belajar. Terbukti dari seluruh siswa mengumpulkan tugasnya tepat waktu, mendokumentasikan tugasnya, dan ikut serta dalam diskusi dan berhasil menemukan konsep terkait materi pencemaran lingkungan.

Dari paparan tersebut diketahui bahwa pembelajaran menggunakan modul praktikum IPA berbasis inkuiri dapat melatih kemandirian belajar siswa. Terlebih lagi di masa pandemi Covid-19 seperti saat ini, keberadaan modul praktikum IPA berbasis inkuiri dalam bentuk $e$-book sangat membantu guru dan siswa dalam melakukan pembelajaran dari rumah secara individu.

\section{SIMPULAN}

Kemandirian belajar siswa SMP Swasta Advent Singkawang Kalimantan Barat dalam memepelajari materi pencemaran lingkungan menggunakan modul praktikum IPA berbasis inkuiri secara umum tergolong sangat baik, sehingga tergolong mandiri. Persentase perolehan terbesar pada aspek percaya diri siswa tergolong sangat baik dengan persentase $62,50 \%$, disiplin siswa tergolong baik dengan persentase, $68,75 \%$ inisiatif siswa tergolong sangat baik dengan persentase 43,75\%, tanggung jawab siswa tergolong baik dengan persentase $43,75 \%$ dan motivasi siswa tergolong sangat baik dengan persentase $43,75 \%$.

\section{DAFTAR RUJUKAN}

Anzora. 2017. Analisis Kemandirian Siswa pada Pembelajaran Matematika dengan
Menerapkan Teori Belajar Humanistik. Jurnal Gantang, 11(2).

Arikunto, S. 2006. Prosedur Penelitian Suatu Pendekatan Praktik (edisi revisi VI). Jakarta: Rineka Cipta.

Fidiana, Lutfi; S., Bambang; D., Pratiwi. 2012. Pembuatan dan Implementasi Modul Praktikum Fisika Berbasis Masalah untuk Meningkatkan Kemandirian Belajar Siswa Kelas XI. UNNES Science Education Journal, 1(1).

Muhafid, Ervian Arif; Dewi, Novi Ratna; Widiyatmoko, Arif. 2013. Pengembangan Modul IPA Terpadu Berpendekatan Keterampilan Proses pada Tema Bunyi di SMP Kelas VIII. UNNES Science Education Journal, 2(1).

Pemerintah Indonesia. (2017). Peraturan Presiden Republik Indonesia No. 87 Tahun 2017 tentang Penguatan Pendidikan Karakter. Jakarta: Kementrian Sekertariat Negara..

Pradana, dkk. 2020. Pengembangan E-Modul Berbasis Mobile Learning Mata Pelajaran Seni Budaya Konsep Budya, Seni dan KeindahanKelas X SMKN 1 Turen Malang. Jurnal Inovasi Teknologi Pembelajaran, 6(2).

Sanjaya, W. 2008. Pembelajaran Dalam Impelentasi Kurikulim Berbasis Kompetensi. Jakarta: Prenada Media Group.

Santoso; Hanif, Achmad Sofyan; Lubis, Johansyah. 2018. Hubungan antara Kesegaran Jasmani, Disiplin dan Percaya Diri Taruna dengan Prestasi Akademik Sekolah Tinggi Transportasi Darat Bekasi Jawa Barat. Jurnal Pendidikan Jasmani dan Adaptif, 1(1).

Suparno, 2007. Metodologi Pembelajaran Fisika Konstruktivistik \& Menyenangkan. Yogyakarta: Universitas Sanata Darma.

Suryani, Cicih Devi. 2018. Peningkatan Kepercayaan Diri melalui Layanan 
Bimbingan Kelompok pada Siswa Kelas $\mathrm{X}$ PS2 SMK Negeri 1 Bandung. Jurnal Penelitian Pendidikan, 18(3).

Uswatun, Din Azwar; Wilujeng, Insih; Hastuti, Purwanti Widhy. 2016. Modul IPA Berbasis Sains Teknologi Masyarakat (STM) untuk Meningktakan Kemandirian Belajar Siswa dan Kemampuan Kognitif Siswa. Jurnal Utile: Jurnal Kependidikan, 2(2).

Wijayanto, D., Sulistina, O., \& Zakia, N. (2011). Pengembangan Buku Petunjuk Praktikum Kimia SMP Berbasis Inkuiri Terbimbing Pada Materi Asam Basa. Universitas Negeri Malang : Malang. 